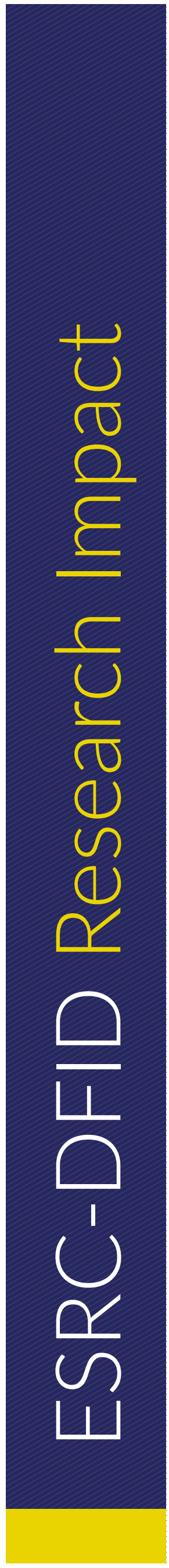

\title{
ENDING THE FINANCIAL ENTRAPMENT OF STREET VENDORS IN COLOMBIA
}

In the global South, the informal economy provides over 50 per cent of urban employment. In Cali, Colombia, the absence of government intervention and financial programmes means that illegal moneylenders are used by workers in the informal economy to keep themselves afloat. Consequently, workers such as street vendors remain beholden to extortionate interest rates. Based on research by POLIS (Observatory of Public Policy) of Universidad ICESI and Cardiff University, the Mayor of Cali has incorporated a financial policy which aims to enable street vendors to borrow money quickly and reasonably, protecting them from turning to the gota-gota moneylenders and empowering them to build a sustainable livelihood.

\section{THE CHALLENGE}

Since the 1980s, Cali has been affected by drug trafficking, and a large number of people displaced by the armed conflict have settled in the city, increasing poverty and social tensions. Fifty-five per cent of Cali's population live in the most impoverished neighbourhoods and at least 50 per cent are estimated to work in the informal sector, many as street vendors.

Street vending requires liquidity daily in order to operate and the lack of access to financial institutions is one of the main drivers behind the widespread use of problematic moneylending (locally known as gota-gota). However, unlike elsewhere in the world,

\begin{abstract}
street vendors in Cali on average earn a relatively high income (about USD440 per month). Despite this, because money is lent at predatory interest rates of over 240 per cent per annum, street vendors remain trapped in poverty with no viable alternative to finance their livelihoods. Street vendors are also extremely vulnerable as violence is commonly used to enforce payments.
\end{abstract}

\section{THE RESEARCH}

Between 2016 and 2019, a research team led by Cardiff University collaborated with partners on the ESRC-DFID-funded project 'Economic Recovery in Post-Conflict Cities: The Role of the Urban Informal

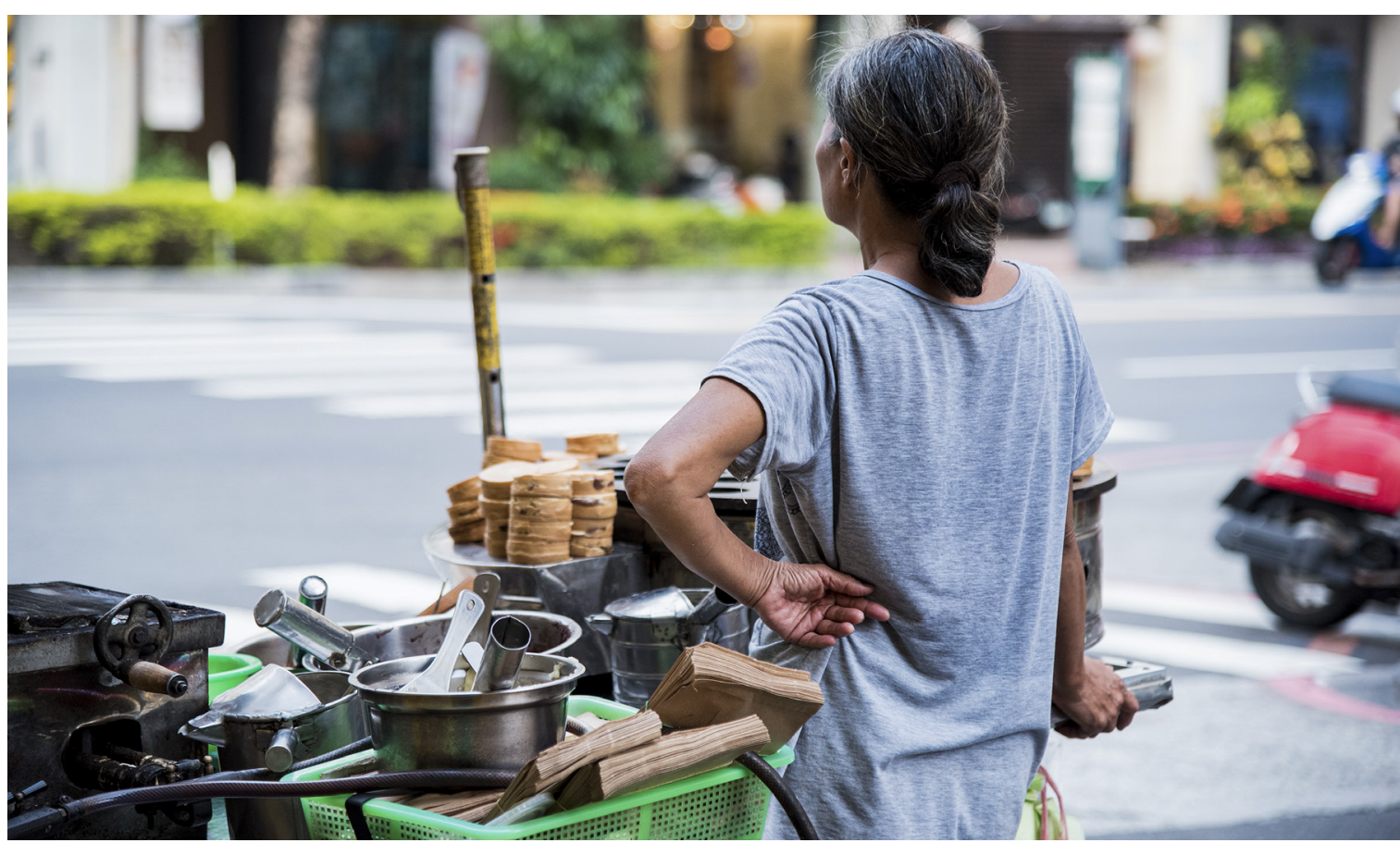

Cover photo: A street vendor waiting to sell her ready-to-eat food. Credit: Abby Chung 
Economy'. The research explored the role of the urban informal economy in poverty reduction and peacebuilding in post-conflict cities, and its scope was to provide livelihoods for the extreme poor and a platform for economic recovery.

In 2018, as part of this project, 527 street vendors operating within and around the mass transit system in Cali answered questionnaires as part of research to understand their financial practices. In addition, 70 semi-structured interviews were conducted with street vendors operating across the city. The findings revealed a lack of formal financial inclusion of street vendors. Ultimately, many of these vendors are caught in financial entrapment and very few of them have either an account or any kind of service with a formal financial institution. Many have had to borrow money from a gota-gota moneylender, and the monthly repayments account for around quarter of their monthly earnings.

\section{THE IMPACT}

Getting the media involved has been pivotal to secure and retain local government attention. A public event, organised with POLIS (Observatory of Public Policy) of Universidad ICESI, the Chamber of Commerce, the mass transit system (MIO), the urban renovation office (EMRU), and the territorial programmes for social inclusion (TIOS), received front-page coverage in the major national newspaper El Pais. A press release was also circulated about the lack of financial inclusion and pay-day loans (gota-gota) in the informal sector. El Pais also published an opinion piece about one of the coercive measures that the government was implementing to regulate street vending in the city and the across country.

In partnership with the urban planning office, informal economy workers and vulnerable populations (e.g. displaced people, women, and minorities) working in the public space were invited to an open forum. This event was an opportunity for the research team to present and discuss their findings and, also, to gain insight to the participants' perspectives on government regulation and its laws relating to public space. Approximately 50 informal economy workers participated.

The city council formally asked the Secretary of Economic Development, Angélica Mayolo, to propose a financial inclusion programme for informal economy workers to be included in the formulation of public policy on economic development in the city. The municipal government Economic Development team adopted a programme called Gota-Ahorro, which was informed by the research findings and promoted by Bank W (formerly the Women's Bank). Bank W agreed to launch a pilot and POLIS plans to evaluate the impact of the programme.

In September 2019, the city council approved the economic development policy for the next ten years. The policy includes a programme called 'Banco de Oportunidades' (Opportunities Bank), through which financial inclusion will be provided to informal economy workers. The next mayor, due to take office in January 2020, will be responsible for implementing the programme.

One of the most significant impacts of this research has been the promotion of dialogue between vendors and the municipal government. Alongside the data, this provides the basis for future development of inclusive financial services for street vendors in Cali.

\section{FURTHER READING}

Cali en Cifras (2018) Departamento Administrativo de Planeación, Santiago de Cali, www.cali.gov.co/ planeacion/publicaciones/137803/documentos-calien-cifras/

Martínez, L.; Brown, A. and Mackie, P. (2019) Local Economic Development, Micro-Enterprise and Crime Reduction: Lessons from Cali, Colombia, ONU-Habitat Discussion Paper, 31 January, www.academia. edu/38261926/LED_micro-enterprise_and_crime_ reduction_Lessons_from_Cali_Colombia

Martínez, L. and Rivera-Acevedo, J.D. (2018) 'Debt Portfolios of the Poor: The Case of Street Vendors in Cali, Colombia', Sustainable Cities and Society 41: 120-5, www.academia.edu/36831609/Debt_portfolios_of the_poor_The_case_of_street_vendors_in_Cali_

\section{Colombia}

Martínez, L. (2019) 'La Lección de la Empanada', El Pais www.elpais.com.co/opinion/columnistas/linamartinez/la-leccion-de-la-empanada.html

El Pais (2018) 'Vendedores Ambulantes Ganan más que el Promedio de los Asalariados de Cali', www.elpais.com.co/economia/vendedoresambulantes-ganan-mas-que-el-promedio-de-losasalariados-de-cali.html

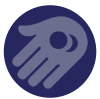

Economic Recovery in Post-Conflict Cities: The Role of the Urban Informal Economy

The research team was funded by ESRC-DFID's Joint Fund for Poverty Alleviation Research, led by Principal Investigator Dr Alison Brown, Cardiff University, together with Dr Peter Mackie, Cardiff University. Dr Lina Maria Martínez Quintero, Universidad ICESI and POLIS, led the research in Colombia.

\section{THE IMPACT INITIATIVE}

\section{For International Development Research}

The Impact Initiative seeks to connect policymakers and practitioners with the world-class social science research supported by the ESRC-DFID Strategic Partnership, maximising the uptake and impact of research from: (i) the Joint Fund for Poverty Alleviation Research, and (ii) the Raising Learning Outcomes in Education Systems Programme. We seek to identify synergies between these programmes and their grant holders, support them to exploit influencing and engagement opportunities, and facilitate mutual learning. The Impact Initiative is a collaboration between the Institute of Development Studies (IDS) and the University of Cambridge's Research for Equitable Access and Learning (REAL) Centre.

All content is available under the Open Government License v3.0, except where otherwise stated.

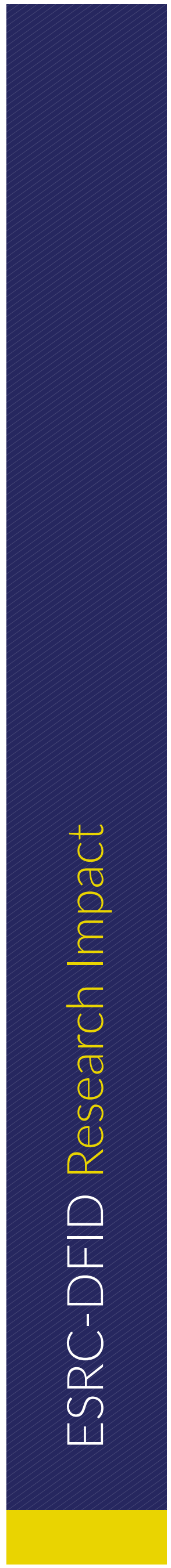

\section{CREDITS}

This impact story was written by Dr Lina Maria Martínez Quintero at Universidad ICESI and POLIS, in collaboration with Vivienne Benson at the Institute of Development Studies.

$\triangle$ info@theimpactinitiative.net www.theimpactinitiative.net @the_Impact_Init \#impactlessons 